\title{
Pengaruh Kombinasi Ekstrak Carica Papaya dan Propolis Terhadap Peningkatan Trombosit
}

\section{The Effect of Combination Carica Papaya Extract and Propolis To Increase Platelets}

\author{
Eka Widya Ningrum Lobang ${ }^{1}$, Icha Maharani Putri ${ }^{1}$, Zidhan Hanafi ${ }^{1}$, Endang \\ Widhiyastuti $^{1}$ \\ wdy07lobang@gmail.com \\ ${ }^{1}$ Sekolah Tinggi Ilmu Kesehatan Nasional \\ Riwayat Artikel: Dikirim Juli 2020; Diterima September 2020; Diterbitkan Oktober 2020
}

\begin{abstract}
Abstrak
Trombosit adalah bagian darah yang berperan saat pembuluh darah rusak akibat robeknya kulit sehingga terjadi perdarahan. Apabila kadar trombosit seseorang $<150.000 \mathrm{sel} / \mu \mathrm{l}$ darah, maka orang tersebut mengalami trombositopenia. Daun pepaya mempunya kandungan untuk meningkatkan trombosit. Selain tanaman pepaya, ada juga propolis yang bisa digunakan sebagai obat anti-inflamasi karena adanya CAPE dan quertecin yang berperan untuk menekan aktifitas sel T. CAPE mampu menginhibisi NF-kB dan stimulant IL-2 yang memacu poliferasi kerja dari sel T. Penelitian ini bertujuan untuk mengetahui apakah ada pengaruh pemberian kombinasi ekstrak daun pepaya dan propolis dalam peningkatan trombosit. Penelitian ini menggunakan metode studi literatur dimana data yang digunakan bersumber dari laporan hasil penelitian, skripsi atau jurnal ilmiah baik nasional maupun internasional dalam rentang 10 tahun terakhir yang berkaitan dengan pengaruh ekstrak daun pepaya terhadap peningkatan trombosit. Hasil penelitian sebelumnya menunjukkan ada pengaruh pemberian ekstrak daun papaya terhadap kenaikan jumlah trombosit ( $p$ 0.00004). Hasil penelitian terdahulu juga menyebutkan bahwa propolis mengandung berbagai macam komponen, seperti flavonoid dan alkaloid. Flavonoid pada propolis mampu mendukung kinerja ekstrak daun papaya dalam meningkatkan jumlah trombosit. Simpulan pada penelitian ini didapatkan pemberian ekstrak daun pepaya cukup efektif untuk meningkatkan jumlah trombosit. Dengan dikombinasikannya ekstrak daun pepaya dan ekstrak propolis dapat membantu mengurangi inflamasi.
\end{abstract}

Kata Kunci: Ekstrak daun pepaya, Ekstrak propolis, trombosit

\begin{abstract}
Platelets are part of the blood that plays a role when blood vessels are damaged due to tearing of the skin, causing bleeding. If a person's platelet level $<150,000$, it's called thrombocytopenia. Papaya leaves have a content to increase platelets. Propolis can be used as an anti-inflammatory drug because of the presence of CAPE and quertecin which play a role in suppressing $T$ cell activity. CAPE is able to inhibit NF- $k B$ and stimulant IL-2 which stimulates the work of $T$ cells. This study aims to determine whether there is an effect of giving a combination of papaya leaf extract and propolis in increasing platelets. This study used a literature study method where the data used come from research reports, theses or scientific journals both national and
\end{abstract}


international in the last 10 years related to the effect of papaya leaf extract on increasing platelets. Previous research has shown there is an effect of papaya leaf extract on the increase in platelet count ( $p$ 0.00004). Previous research has also mentioned that propolis contains a variety of components, such as flavonoids and alkaloids. Flavonoids in propolis are able to support the performance of papaya leaf extract in increasing the number of platelets. The conclusion in this study was that the papaya leaf extract was effective enough to help increase the platelet count. The combination of papaya leaf extract and propolis extract can help reduce inflammation.

Keywords: Papaya leaf extract, Propolis extract, Platelets

\section{Pendahuluan}

Trombosit atau biasa disebut platelet merupakan fragmen sitoplasma megakariosit yang tidak berinti dan terbentuk di sum sum tulang, serta bentuk matangnya berukuran 2-4 $\mu \mathrm{m}$ dan berbentuk cakram bikonveks. Trombosit merupakan bagian darah yang paling berperan saat pembuluh darah rusak maupun kulit mengalami luka dan bocor yang mengakibatkan darah keluar dari pembuluh atau terjadi perdarahan. Pada manusia, jumlah trombosit normal berkisar antara 150.000$400.000 \mathrm{sel} / \mu \mathrm{l}$ darah. Apabila kadar trombosit seseorang kurang dari 150.000 sel / $\mu$ l darah, maka orang tersebut mengalami kekurangan trombosit atau yang biasa disebut trombositopenia (Durachim dan Dewi, 2018). Terjadinya trombositopenia disebabkan oleh dua faktor yaitu, karena gangguan produksi trombosit dan karena kerusakan yang berlebihan. Trombositopenia karena gangguan produksi trombosit misalnya pada kasus anemia megaloblastik, leukimia, myeloma, myelo-fibrosis, anemia aplastik dan infiltrasi tumor padat, sedangkan trombositopenia karena kerusakan yang berlebihan misalnya pada kasus penyakit autoimun ITP, SLE, infeksi virus antara lain dengue dan HIV. Trombositopenia merupakan penyebab umum terjadinya gangguan hemostasis primer yang bisa menyebabkan perdarahan yang signifikan (Saraf dan Bhushan, 2017).

Indonesia sebagai negara tropis memiliki aneka ragam tanaman yang tersebar di berbagai nusantara dan dalam kehidupan sehari-harinya pun, masyarakat Indonesia sulit dipisahkan dengan obat tradisional. Berbagai macam tumbuh-tumbuhan yang ada di alam dapat dimanfaatkan untuk mengobati berbagai penyakit, salah satunya adalah daun papaya. Daun papaya biasanya dimanfaatkan oleh masyarakat untuk menurunkan panas, mengurangi nyeri saat haid, serta mengobati masalah pada saluran pencernaan. Menurut Srikanth, et al, (2019) ekstrak daun pepaya dapat meningkatkan jumlah trombosit. Hasil analisis fitokimia menunjukkan bahwa daun papaya (Carica papaya L.) mengandung alkaloid, triterpenoid, steroid, flavonoid, saponin, tannin, papain, chymopapain, cystatin, tocopherol, dan lain sebagainya (A'yun dan Ainun, 2015; Pamungkas, et al., 2020).

Tabel I. Kandungan fitokimia di dalam ekstrak daun papaya

\begin{tabular}{cl}
\hline No & Kandungan Ekstrak Daun Pepaya \\
\hline 1 & Saponin \\
2 & Flavonoid \\
3 & Glikosida \\
4 & Gula pereduksi \\
5 & Steroid \\
6 & Tannin \\
7 & Alkaloid \\
\hline
\end{tabular}

Propolis atau yang juga sering disebut sebagai sarang lebah merupakan suatu senyawa yang diperoleh dari aktivitas lebah yang telah diketahui mempunyai efek anti-inflamasi, antioksidan, antiviral, antimitogenik, antikarsinogen, dan efek imunomodulator (Rochsismandoko, et al., 2013). Komposisi kimia dari propolis secara umum terdiri dari 50\% resin, 30\% lilin, 10\% minyak atsiri, 5\% serbuk sari dan 5\% zat lain seperti asam fenolik, azam benzoat, asam amino dan flavonoid. Komponen utama dari propolis adalah flavonoid dan asam fenolat termasuk CAPE (Caffeic Acid Phenetyl Ester) yang kandungannya mencapai $50 \%$ dari seluruh komposisi. Propolis telah digunakan secara luas pada beberapa model penyakit dan menunjukan potensi besar sebagai pelindung respon imun tubuh. Propolis digunakan sebagai obat anti-inflamasi karena kandungan 
CAPE dan quertecin yang berperan untuk menekan aktifitas sel T. CAPE mampu menginhibisi Nuklear Transcription Factor Kappa $B$ (NF-kB) dan stimulant IL-2 yang memicu poliferasi kerja dari sel T sendiri (Putri, 2014).

\section{Metode Penelitian}

Penelitian ini menggunakan jenis penelitian studi literatur. Data yang digunakan dalam penelitian ini bersumber dari laporan hasil penelitian, skripsi atau jurnal ilmiah baik nasional maupun internasional dalam rentang 10 tahun terakhir yang berkaitan dengan pengaruh ekstrak daun pepaya terhadap peningkatan trombosit dan kandungan fitokimia propolis. Data-data yang diambil berupa prosedur kerja, metode pemeriksaan, hasil penelitian, serta teori pendukung hasil penelitian, kemudian diolah dalam bentuk tabel.

\section{HASIL DAN PEMBAHASAN}

Pada penyusunan narrative review ini, terdapat delapan jurnal penelitian yang dijadikan acuan utama dalam penyusunanya.

Tabel II. Karakteristik Populasi dan Sampel Carica papaya

\begin{tabular}{|c|c|c|c|c|}
\hline & $\begin{array}{l}\text { Dharmarathna, } \\
\text { et al (2013) }\end{array}$ & $\begin{array}{l}\text { Tahir, et al } \\
\text { (2014) }\end{array}$ & $\begin{array}{l}\text { Guruprasad, et al } \\
\text { (2015) }\end{array}$ & $\begin{array}{c}\text { Kumar, et al } \\
\text { (2018) }\end{array}$ \\
\hline Populasi & Tikus putih jantan & $\begin{array}{c}\text { Tikus Swiss albino } \\
\text { dewasa }\end{array}$ & Tikus wistar albino & $\begin{array}{c}\text { Tikus albino jantan } \\
\text { dan betina }\end{array}$ \\
\hline Sampel & Tidak disebutkan & Cardiac puncture & $\begin{array}{c}\text { Pengambilan sampel } \\
\text { darah dari sinus retro } \\
\text { orbital }\end{array}$ & $\begin{array}{l}\text { Sinus vena medial retro- } \\
\text { orbital }\end{array}$ \\
\hline Jumlah Sampel & 18 & 11 & 6 & 6 \\
\hline Kriteria Sampel & $\begin{array}{l}\text { - Berat 32-33 gram } \\
\text { - Usia } 6 \text { minggu }\end{array}$ & $\begin{array}{l}\text { - Tikus berasal dari } \\
\text { Veterinary Research } \\
\text { Institute Lahore dengan } \\
\text { berat 35-45 gram } \\
\text { - Tikus diinduksi satu } \\
\text { suntikan } \\
\text { intraperitoneal }\end{array}$ & $\begin{array}{l}\text { - Tikus berasal dari Animal } \\
\text { House Departemen } \\
\text { Farmakologi, Nitte } \\
\text { University, Mangalore, } \\
\text { Karnataka } \\
\text { - Berat } 290 \pm 10 \text { gr }\end{array}$ & $\begin{array}{l}\text { - Tikus berasal dari } \\
\text { rumah hewan } \\
\text { departemen } \\
\text { Farmakologi, JJM } \\
\text { Medical College dengan } \\
\text { berat 100-125 gram } \\
\text { - Tikus uii diinduksi }\end{array}$ \\
\hline & & $\begin{array}{l}\text { intraperitoneal } \\
\text { karboplatin } \\
\text { mg/15 mL }\end{array}$ & $\begin{array}{l}\text { - Tikus uji diinduksi } \\
\text { hidroxyurea } 1.6 \mathrm{mg} / \mathrm{kg}\end{array}$ & $\begin{array}{l}\text { - Tikus uj1 dilnduks1 } \\
\text { hidroxyurea } \\
\text { mg/kg) secara oral }\end{array}$ \\
\hline Cara Memperoleh & Jus daun pepaya & Tumbukan daun & Jus daun pepaya disaring & Tumbukan daun \\
\hline Ekstrak Daun & disaring & pepaya diperas & (tanpa penambahan air) & pepaya diperas \\
\hline Pepaya & $\begin{array}{c}\text { (tanpa } \\
\text { penambahan air) }\end{array}$ & $\begin{array}{l}\text { (tanpa penambahan } \\
\text { air) }\end{array}$ & & $\begin{array}{l}\text { (tanpa penambahan } \\
\text { air) }\end{array}$ \\
\hline $\begin{array}{l}\text { Metode Pemeriksaan } \\
\text { Jumlah Trombosit }\end{array}$ & Sediaan apus darah & Tidak disebutkan & $\begin{array}{c}\text { HemaTrue bematology } \\
\text { analyzer }\end{array}$ & Manual (kamar hitung) \\
\hline
\end{tabular}

Tabel II menjelaskan mengenai karakteristik populasi dan sampel dari masing-masing jurnal penelitian yang dijadikan acuan dalam penelitian studi literatur ini.

Tabel III. Kandungan Fitokimia Propolis

\begin{tabular}{|c|c|c|c|c|}
\hline & $\begin{array}{c}\text { Kurniawati, et al } \\
\text { (2013) }\end{array}$ & $\begin{array}{c}\text { Thamrin, et al } \\
\text { (2016) }\end{array}$ & $\begin{array}{l}\text { Khairunnisa, et al } \\
(2020)\end{array}$ & $\begin{array}{c}\text { Khairunnisa, } \mathrm{K} \text {, et al } \\
(2020)\end{array}$ \\
\hline Sampel & $\begin{array}{c}\text { Propolis Trigona } \\
\text { sp }\end{array}$ & $\begin{array}{c}\text { Propolis } \\
\text { Trigona incisa }\end{array}$ & $\begin{array}{c}\text { Propolis Tetragonula } \\
\text { iridipennis }\end{array}$ & Propolis Trigona $\mathrm{sp}$ \\
\hline $\begin{array}{l}\text { Metode } \\
\text { ekstraksi }\end{array}$ & Maserasi & Maserasi & Maserasi & Maserasi \\
\hline Uji & - Alkaloid & - Alkaloid & - Alkaloid & - Alkaloid \\
\hline fitokimia & $\begin{array}{l}\text { - Flavonoid } \\
\text { - Steroid } \\
\text { - Triterpenoid } \\
\text { - Saponin } \\
\text { - Minyak atsiri }\end{array}$ & - Fenolik & $\begin{array}{l}\text { - Flavonoid } \\
\text { - Triterpenoid } \\
\text { - Tanin } \\
\text { - Karbohidrat }\end{array}$ & $\begin{array}{l}\text { - Flavonoid } \\
\text { - Fenolik } \\
\text { - Tanin }\end{array}$ \\
\hline
\end{tabular}


Eka Widya Ningrum Lobang, Icha Maharani Putri,

Zidhan Hanafi, Endang Widhiyastuti

Tabel III menjelaskan mengenai berbagai kandungan fitokimia yang terdapat di dalam propolis, dimana disebutkan bahwa propolis ini mengandung flavonoid dan alkaloid yang dapat membantu meningkatkan jumlah trombosit dan juga membantu mengurangi inflamasi.

Tabel IV. Statistik Deskriptif Ekstrak Daun Pepaya Dalam Meningkatkan Jumlah Trombosit

\begin{tabular}{ccccc}
\hline & Dharmarathna, et al & Tahir, et al & Guruprasad, et al & Kumar, et al \\
& 2013 & 2014 & 2015 & 2018 \\
& Hari-3 & Hari- 7 & Hari-5 & Hari-6 \\
\hline Mean \pm SD & $(3.4 \pm 0.18) \times 10^{5} / \mu \mathrm{L}$ & Jantan : & $(697.66+212.36) \times$ & $(4.69 \pm 3.13)$ \\
& \multicolumn{4}{c}{} \\
& $(718 \pm 48) \times 10^{9} / \mathrm{L}$ & $10^{3} / \mathrm{mL}$ & Lakhs $/ \mathrm{mm}^{3}$ \\
& Betina : \\
& $(700 \pm 38) \times 10^{9} / \mathrm{L}$ \\
\hline
\end{tabular}

Tabel V. Hasil Uji Statistik Ekstrak Daun Pepaya Dalam Meningkatkan Jumlah Trombosit

\begin{tabular}{|c|c|c|c|c|}
\hline & $\begin{array}{c}\text { Dharmarathna, et al } \\
2013 \\
\text { Hari-3 } \\
\end{array}$ & $\begin{array}{c}\text { Tahir, } \text { et al } \\
2014 \\
\text { Hari-7 } \\
\end{array}$ & $\begin{array}{c}\text { Guruprasad, et al } \\
2015 \\
\text { Hari-5 } \\
\end{array}$ & $\begin{array}{c}\text { Kumar, } \text { et al } \\
2018 \\
\text { Hari-6 } \\
\end{array}$ \\
\hline Pvalue & 0.00004 & $\leq 0.001$ & $<0.05$ & $<0.018$ \\
\hline Kesimpulan & $\begin{array}{l}\text { Ekstrak daun } C \text {. } \\
\text { papaya segar secara } \\
\text { signifikan dapat } \\
\text { meningkatkan jumlah } \\
\text { trombosit dan sel } \\
\text { darah merah pada } \\
\text { kelompok uji }\end{array}$ & \begin{tabular}{lr}
\multicolumn{2}{l}{ Pemberian jus da } \\
pepaya & dal \\
mencegah & \\
penurunan & jum \\
trombosit & pa \\
tikus & ya \\
diinduksi & \\
karboplatin &
\end{tabular} & $\begin{array}{l}\text { Ekstrak daun } \\
\text { pepaya dapat } \\
\text { meningkatkan } \\
\text { jumlah trombosit } \\
\end{array}$ & $\begin{array}{l}\text { Ekstrak daun } C \text {. } \\
\text { papaya segar maupun } \\
\text { dalam bentuk sediaan } \\
\text { komersial } \\
\text { menunjukkan } \\
\text { peningkatan jumlah } \\
\text { trombosit } \\
\text { signifikan pada } \\
\text { normal maupun } \\
\text { tikus trombositopeni }\end{array}$ \\
\hline
\end{tabular}

Hasil analisis data dari jurnal acuan di atas, pada penelitian Dharmarathna, et al, (2013) yang meneliti peningkatan jumlah trombosit terhadap pemberian ekstrak daun papaya dengan dosis $0.2 \mathrm{~mL}(2 \mathrm{~g}) /$ tikus, didapatkan jumlah trombosit (3.4 \pm 0.18$) \times 10^{5} / \mu \mathrm{L}$. Hasil tersebut kemudian diuji statistik dan disimpulkan bahwa terdapat kenaikan jumlah trombosit yang signifikan terhadap pemberian ekstrak daun pepaya $(P=0.00004)$. Jurnal penelitian yang kedua adalah milik Tahir, et al, (2014) yang melakukan penelitian pada 11 tikus yang telah memenuhi kriteria yang ditentukan, mengenai hubungan ekstrak daun pepaya dengan dosis $5 \mathrm{ml} / \mathrm{kg}$ dengan peningkatan jumlah trombosit didapatkan hasil $(718 \pm 48) \times 10^{9} / \mathrm{L}$ pada tikus jantan dan $(700 \pm 38) \times 10^{9} / \mathrm{L}$ pada tikus betina. Berdasarkan uji statistik yang dilakukan terjadi peningkatan yang signifikan pada pemberian ekstrak daun pepaya terhadap peningkatan jumlah trombosit $(P \leq 0.001)$.

Jurnal acuan yang ketiga adalah dari Guruprasad, et al, (2015) yang meneliti pemberian ekstrak daun papaya dengan dosis $7.2 \mathrm{ml} / \mathrm{kg}$ terhadap peningkatan trombosit pada tikus, didapatkan hasil jumlah trombosit $(697.66 \pm 212.36) \quad \mathrm{x} 10^{3} / \mathrm{mL}$. Hasil dari uji statistik dari data tersebut menyatakan bahwa terjadi peningkatan jumlah trombosit dengan nilai $\mathrm{p}(P<0.05)$. Serta jurnal penelitian yang keempat adalah penelitian dari Kumar, et al, (2018) yang meneliti mengenai pemberian ekstrak daun pepaya dengan dosis 0.36 $\mathrm{mL} / 100 \mathrm{gm} /$ hari terhadap peningkatan trombosit pada tikus, didapatkan hasil jumlah trombosit (4.69 \pm 3.13$)$ Lakhs $/ \mathrm{mm}^{3}$. Hasil dari uji statistik dari data tersebut menyatakan bahwa terjadi peningkatan jumlah trombosit dengan nilai $\mathrm{p}(P<0.018)$.

\section{Pembahasan}

Berdasarkan jurnal penelitian yang digunakan sebagai acuan, peneliti sebelumnya menggunakan tikus putih sebagai hewan uji coba. Tikus putih digunakan peneliti karena 
memiliki kesamaan struktur dengan manusia. Sifat dari tikus putih yang tidak mudah muntah karena struktur anatomi dimulai dari esofagus dilanjutkan ke dalam lambung menjadi alasan kenapa peneliti sering menggunakan hewan ini dalam percobaan penelitian (A'yun, 2019).

Pemberian ekstrak daun pepaya kepada hewan uji terdapat dua perbedaan. Menurut jurnal penelitian Dhamarathna, et al, (2013) dan Guruprasad, et al, (2015) ekstrak diperoleh dari penyaringan jus daun pepaya. Daun pepaya yang masih segar dicuci hingga bersih dan batang dari daun pepaya dibuang. Setelah dilakukan penimbangan, daun pepaya diblender tanpa adanya penambahan air atau cairan lain, kemudian disaring untuk mendapatkan ekstrak daun Carica papaya yang murni. Menurut Tahir, et al, (2014) dan Kumar, et al, (2018) melalui perasan tumbukan daun pepaya. Daun pepaya segar dicuci hingga bersih untuk menghilangkan debu yang menempel. Selanjutnya daun ditumbuk dan diperas menggunakan kain muslin untuk mendapatkan sarinya. Dalam proses ini tidak ada penambahan air ataupun cairan lain.

Daun papaya atau nama latinnya Carica papaya L memiliki kandungan alkaloid, triterpenoid, steroid, flavonoid, saponin, tannin, papain, chymopapain, cystatin, dan tocopherol (A'yun dan Ainun, 2015; Pamungkas, et al., 2020). Salah satu golongan flavonoid yang efektif secara cepat menaikkan jumlah trombosit melalui mekanisme peningkatan jumlah sitokin, terutama GM-CSF (Granulocyte Macrophage-Colony Stimulating Factor), IL-3 (Interleukin-3) dan rangsangan proliferasi dan diferensiasi tersebut dikontrol oleh TNFa (Tumor Necrosis Factor-a) dan IL3, sehingga dapat meningkatkan jumlah trombosit dalam darah. Flavonoid juga dapat meningkatkan jumlah megakariosit dalam sumsum tulang, sehingga dapat meningkatkan jumlah trombosit dalam darah (Soegijanto, et al., 2010).

Berbagai penelitian ekstrak daun papaya telah terbukti dapat meningkatkan jumlah trombosit, hal ini dapat dikaitkan dengan sitokin trombopoietik yang diregulasi seperti IL-6, SCF (Stem Cell Factor), IL-3 dan TPO (trombopoietin) sebagai respons terhadap ekstrak daun papaya (Agustina, 2019). Penelitian Aziz, et al, (2015), mengungkapkan bahwa ekstrak daun papaya banyak mengandung papain, dimana pada pasien demam berdarah dengue, komponen tersebut berpotensi untuk menginduksi sintesis IL-6 yang akan menstimulasi ekspresi trombopoietin di hati, sehingga trombopoiesis atau megakariopoiesis terjadi. Hal ini juga sejalan dengan penelitian Subenthiran, et al, (2013), dimana konsumsi ekstrak daun papaya menunjukkan adanya peningkatan aktivitas gen di dalam tubuh manusia yaitu, ALOX dan PTAFR. Peningkatan Arachidonate 12lipoxygenase (ALOX 12) dan Reseptor Faktor Aktivasi Trombosit (PTAFR) diperlukan untuk produksi dan aktivasi trombosit. Gen ALOX 12 diekspresikan dalam megakariosit dan bertanggung jawab atas produksi 12Hydroxyeicosatetraenoic Acid (12-HETE) dari trombosit. Sedangkan gen PTAFR ditemukan dan diekspresikan dalam megakariosit yang mengindikasikan bahwa gen tersebut dapat menjadi prekursor produksi trombosit dan gen ini juga berperan terhadap aktivitas agregasi trombosit.

Dari jurnal acuan yang diambil, dapat kita ketahui bahwa ekstrak daun pepaya yang diperoleh dengan metode sederhana, yaitu dengan menghancurkan daunnya dan kemudian diambil sarinya dapat menunjukkan terjadinya peningkatan jumlah trombosit pada hewan uji. Menurut Yunita, et al, (2012), daun pepaya terbukti mengandung banyak komponen aktif seperti papain, chymopapain, cystatin, tocopherol, ascorbic acid, flavonoids, cyanogenic-glucosides, glucosinolates, cardiac glycosides, anthraquinones, carpaine, pseudocarpaine, dan komponen fenolik. Kandungan enzim seperti papain dan chymopapain pada daun pepaya dapat membantu meningkatkan jumlah trombosit, serta flavonol dan flavonoid memiliki efek stimulan pada produksi sel darah (Sundarmurthy, et al., 2017). Aziz, et al, (2015) melakukan penelitian terhadap pasien demam berdarah dengue, dimana kandungan enzim papain pada ekstrak daun pepaya terbukti berpotensi untuk menginduksi sintesis IL-6 yang akan menstimulasi ekspresi trombopoietin di hati, sehingga trombopoiesis atau megakariopoiesis terjadi. Sedangkan flavonoid mampu meningkatkan trombosit dengan merangsang GM-CSF (Granulocyte Macrophage Colony-Stimulating Factor) dan IL-3 (Interleukin-3). GM-CSF dan IL-3 ini merupakan hormon yang berfungsi untuk 
memicu pembentukan sel megakariosit (Prasetyaningsih, et al., 2018).

Jurnal-jurnal acuan yang diambil juga menyebutkan bahwa propolis mengandung berbagai macam komponen, diantaranya adalah flavonoid, alkaloid, tannin, dan lain sebagainya. Flavonoid yang terkandung pada propolis ini diharapkan mampu mendukung kinerja dari ekstrak daun pepaya dalam meningkatkan jumlah trombosit, sedangkan kandungan CAPE (Caffeic Acid Phenetyl Ester) berperan sebagai anti-inflamasi. Menurut Kiyota, et al, (2010) CAPE dapat dengan mudah masuk ke dalam sel dan menginhibisi pelepasan sitokin inflamasi dan meningkatkan produksi sitokin anti-inflamasi seperti IL-10 dan IL-4. Stimulan IL-10 berperan sebagai anti-inflamasi yang dapat menurunkan regulasi produksi IL-5 oleh sel T, sedangkan IL-4 dapat menekan aktivitas sitotoksis makrofag membunuh parasit, dan produksi nitric oxide yang diturunkan dari makrofag. Hasil penelitian Korish dan Arafa (2011), menunjukkan bahwa efek antiinflamasi, antioksidan, dan kemampuan untuk menghambat produksi NF- $x \mathrm{~B}$ merupakan mekanisme protektif yang dimiliki CAPE.

\section{Simpulan}

Pemberian ekstrak daun pepaya ini cukup efektif untuk membantu meningkatkan jumlah trombosit pada tikus normal ataupun pada tikus trombositopenia. Kandungan flavonoid pada propolis dapat membantu kinerja ekstrak daun papaya dalam meningkatkan jumlah trombosit, serta kandungan CAPE dapat membantu mengurangi inflamasi yang terjadi. Dengan dikombinasikannya ekstrak daun pepaya dan ekstrak propolis diharapkan selain bisa meningkatkan jumlah trombosit, juga bisa membantu mengurangi inflamasi yang dapat terjadi, mengingat propolis ini memiliki banyak peran untuk kesehatan salah satunya sebagai anti-inflamasi.

\section{Saran}

Dilakukan penelitian secara langsung sehingga dapat mengetahui seberapa efektif daun papaya dan ekstrak propolis yang diekstrak dengan cara maserasi terhadap peningkatan jumlah trombosit. Selain itu, diharapkan pada penelitian selanjutnya juga dapat menentukan metode ekstraksi yang paling baik untuk pembuatan ekstrak daun papaya dan ekstrak propolis.

\section{Ucapan Terimakasih}

Puji syukur kehadirat Tuhan Yang Maha Esa yang telah memberikan rahmatNya sehingga penulis dapat menyelesaikan ini. Penulis tidak lupa mengucapkan terima kasih kepada semua pihak yang tidak mungkin disebutkan satu persatu yang telah membantu penulisan jurnal ini.

\section{Daftar Pustaka}

A'yun, Q. dan A.N. Laily. 2015. Analisis Fitokimia Daun Pepaya (Carica papaya L.) di Balai Penelitian Tanaman Aneka Kacang dan Umbi, Kendalpayak, Malang. Seminar Nasional Konservasi dan Pemanfaatan Sumber Daya Alam, 134-137.

Agustina, A. 2019. Review: Pengaruh Daun Pepaya (Carica Papaya L.) Terhadap Peningkatan Trombosit Pada Pasien Demam Berdarah Dengue. Jurnal Dunia Farmasi, 4(1):34-44.

Aziz, J. Lide, N. Kassim, A. Hayaty, N. Kasim, A. Haque, N., et al. 2015. Carica papaya Induces In-Vitro Thrombopoietic Cytokines Secretion by Mesenchymal Stem Cells and Haematopoietic Cells. BMC Complement Altern Med, 1-8.

Dharmarathna, SLCA., Susiji W., Roshitha NW., et al. 2013. Does Carica papaya leafextract increase the platelet count? An experimental study in a murine model. Asian Pac J Trop Biomed, 3(9):720-724. doi:10.1016/S2221-1691(13)60145-8.

Durachim, A. dan D. Astuti. 2018. Baban Ajar Teknologi Laboratorium Medik (TLM) : Hemostasis. Kementerian Kesehatan Republik Indonesia. Jakarta.

G., Aravind, et al. 2013. Traditional and Medicinal Uses of Carica papaya. Journal of Medicinal Plants Studies, 1(1):7-15.

Guruprasad, R. Dasaraju, dan Thejaswini M. 2015. Effect of Carica Papaya Leaf Extract on Hydroxyurea Induced Hematological and Biochemical Parameters in Wistar Albino Rats. International Journal of Therapeutic Applications, 26:1-5. 
Khairunnisa, B., E. Rosamah, H. Kuspradini, I.W. Kusuma, Sukemi, N.Tandirogang, E.T. Arung1. 2020. Uji Fitokimia dan Antioksidan Ekstrak Etanol Propolis Lebah Kelulut (Tetragonula iridipennis) dari Samarinda Kalimantan Timur. Jurnal Ilmiah Manuntung, 6(1):65-69.

Khairunnisa, K., E. Mardawati, S.H. Putri. 2020. Karakteristik Fitokimia dan Aktivitas Antioksidan Ekstrak Propolis Lebah Trigona sp. Jurnal Industri Pertanian, 2(1):124-129.

Kumar, MS., Geetha M., MJ Shah, et al. 2018. Evaluation of efficacy of Carica papaya leaf extracts to increase platelet count in hydroxyurea induced thrombocytopenia in Albino rats. International Journal of Basic \& Clinical Pharmacology, 7(1):173-178.

Korish AA, Arafa MM. 2011. Propolis derivatives inhibit the systemic inflammatory response and protect hepatic and neuronal cells in acute septic shock. Braz J Infect Dis, 15(4):332-8.

Kurniawati, D., H. Ritonga, dan D. Wulandari. 2013. Isolasi dan Uji Aktivitas Antimikroba Ekstrak Etanol Propolis Trigona spp. Jurnal Progres Kimia Sains, 3(2):74-80.

Mubarak, Zaki et al.2016.Aktivitas Antibakteri Ekstrak Propolis Alami Dari Sarang Lebah Terhadap Pertumbuhan Enterococcus faecalis. Journal Of Syiah Kuala DENTISTRY SOCIETY vol 1 (2) p.175186.

Pamungkas, K.M.N., P.I.L.S. Dewi., dan E.K. Tandiono. 2020. Potensi Quercetin dalam Ekstrak Daun Psidium guajava dan Papain dalam Ekstrak Daun Carica papaya Linn sebagai Terapi Demam Berdarah Dengue. Essential : Essence of Scientific Medical Journal, 17(2):22-28.

Saraf, M. dan B. Kavimandan. 2017. Animal Trials of Carica Papaya Leaf Extracts for Increasing Platelet Count. Indian Journal of Public Health Research \& Development 8(4):782-787.
Sari, Dwi Puspita, et al. 2016.Pengaruh Ekstrak Daun Pepaya (Carica papaya L.)terhadap efek sedasi pada mencit (Mus muculus L.) dan sumbangannya pada pembelajaran biologi SMA jurnal pembelajaran biologi volume 3(2) p183-189.

Shubham, S., et al. Phytochemical Analysis of Papaya Leaf Extract: Screening Test. EC Dental Science, 18(3):485-490.

Srikanth, B.K., et al. 2019. An open-label, randomized prospective study to evaluate the efficacy and safety of Carica papa leaf extract for thrombocytopenia associated with dengue fever in pediatric subjects. Pediatric Health, Medicine and Therapeutics 10:5-11.

Subenthiran, S., MB Teck, KC Cheong, dan A. Afzan. 2013. Carica papaya Leaves Juice Significantly Accelerates the Rate of Increase in Platelet Count among Patients with Dengue Fever and Dengue Haemorrhagic Fever. Evidence-Based Complementary and Alternative Medicine, 2013:1-7.

Sundarmurthy, D. Jayanthi, C.R, Lakshmaiah, K.C. 2017. Effect of Carica papaya Leaf Extract on Platelet Count in Chemotherapy-Induced

Thrombocytopenic Patients: A preliminary study. National Journal of Physiology, Pharmacy and Pharmacology, $7(7): 1-8$.

Tahir, N., Z. Zaheer, S. Kausar, et al. 2014. Prevention of Fall in Platelet Count by Carica papaya Leaf Juice in Carboplatin Induced. Biomedica, 30(1):21-25.

Thamrin, A., Erwin, dan Syafrizal. 2016. Uji Fitokimia,Toksisitas serta Antioksidan Ekstrak Propolis Pembungkus Madu Lebah Trigona incisa dengan Metode 2,2-diphenyl-1-picrylhidrazyl (DPPH). Jurnal Kimia Mulawarman, 14(1):56-60

Thamrin, A., Erwin, dan Syafrizal. 2016. Uji Fitokimia,Toksisitas serta Antioksidan Ekstrak Propolis Pembungkus Madu Lebah Trigona incisa dengan Metode 2,2-diphenyl-1-picrylhidrazyl (DPPH). Jurnal Kimia Mulawarman, 14(1):56-60 